\title{
Leadership Training Moves Ahead
}

\section{The Work of the Development Committee on Internships, Scholarships and Fellowships in Adult Education}

\section{By Watson Dickerman}

Associate Professor of Education, University of Michigan

FOR MANY YEARS adult educators have been saying that their greatest need is more trained leaders. Last summer saw the start of a promising attempt to catch up with this shortage.

Here are a few examples of what was going on last year. A young college teacher who had had enough experience with adult education to whet his appetite was serving an internship in the extension division of a state university. Six union officers were learning how to conduct labor education programs at a mid-western university. Several laymen, including two farmers, were at a workshop in leadership training. The chief of the bureau of adult education in a large eastern state was visiting adult education programs in various parts of the country. Two high school teachers who had felt the challenge of adult education were learning the intricate processes of community adult education in two western states. Several other persons were studying educational television at the only university which operates its own television station.

Well, so what? you may ask. This sort of thing happens every year. True. The point is that these leadership training activities were in aldition to what happens every year, that they were part of a bold and comprehensive plan to end the shortage of trained adult educators, and that they were backed by the deep interest and resources of the Fund for Adult Education.

The Fund's interest in training leaders for the adult education movement is not new. It has been evident in such Fund-aided activities as the American $\mathrm{Heritage}$ Project, the American Foundation for Political Education, the World Affairs Are Your Affairs program, the Center for the Study of Liberal Education for Adults, and the continuation of the Great Books program. The Test Cities project is an experiment in the coordination of leadership in adult education in a score of communities. The three new films on discussion leadership also come to mind, as does the training magazine for group, organization and community leaders, Adult Leadership.

What is new in adult education activities supported by the Fund for Adult Education are two programs of grants for training leaders. One is concerned with the mass media, the other with general adult education. I will not attempt to describe the mass media program in this article, except to say that its initial emphasis has been on educational television and that training programs have already been conducted involving NBC, CBS, Dumont, WOI-TV at Ames, Iowa, and communications centers at several other universities. Through these training programs, future program directors and producers of educational television are being prepared. 


\section{The Development Committee}

We turn now to the program of grants for training leaders in general adult education. The way the Fund has gone about planning this program has gratified adult educators almost as much as the existence of the grants themselves. The Fund officials asked adult educators to plan the training program, to set up a pilot project to test their plan, and to revise the plan in the light of what happened.

The group appointed by the Fund to carry on this work was known as the Development Committee on Internships, Scholarships and Fellowships in Adult Education. Its members were: L. H. Adolfson, University of Wisconsin; A. Craig Baird, State University of Iowa; Robert J. Blakely, Fund for Adult Education*; Leland P. Bradford, National Education Association; Ralph N. Campbell, Cornell University; Edgar Dale, Ohio State University; Grace L. Coyle, Western Reserve University; John S. Diekhoff, Center for the Study of Liberal Education for Adults; Paul L. Essert, Columbia University; Robert B. Hudson, University of Illinois; Howard Y. McClusky, Universiry of Michigan; Paul H. Sheats, University of California (chairman).

The Committee discussed at length the kinds of positions in which trained leaders are particularly needed, the kinds of training situations which could best provide the needed experiences, the kinds of institutions which could best provide these situations, and the kinds of workers in

*Robert J. Blakely was the liaison between the Committee and the Fund. Ronald Shilen, also of the Fund for Adult Education, was executive secretary of the Committee. Inquiries regarding this program should be addressed to $\mathrm{Mr}$. Shilen at the Fund for Adult Education, 141 W. Jackson Blvd., Chicago, Ill. adult education who could profit most from such training.

\section{The Pilot Training Project}

It was evident to the Committee that a wide variety of training situations was needed, from short-term informal study awards to long-term scholarships and fellowships on a level equivalent to study for M.A. and Ph.D. degrees.

The Committee then set up a pilot project to test the plans it had made for study awards, as distinct from long-term scholarships and fellowships. Committee members interviewed persons who were interested in the kinds of training which the Committee felt should be provided, and also interviewed staff members of institutions which could offer the needed training. Where possible, prospective trainees and supervisors were brought together for exploratory conferences. Selections we r e made in the late summer of 1952 , and most of those who were chosen went to their training posts in the late summer or early fall of that year, some for as brief a period as two weeks and some for as long as 12 months.

Of the 49 trainees, 35 were men and 14 were women. Most were married. Their age range was from 23 to 61 , with most under 40 . Approximately one-third were laymen, one-third were professional practitioners or teachers, and one-third were administrators. The largest individual grant was $\$ 3500$; the smallest, $\$ 150$; the average, $\$ 1307$.

The pilot project provided training in the following areas of adult education:

Community education and analysis.17 Education in world affairs....... 3 Community-school relations ...... 1 Film forum administration ....... 1 Guidance in adult education...... 1 
Human relations $\ldots \ldots \ldots \ldots \ldots \ldots 2$

Human rights $\ldots \ldots \ldots \ldots \ldots \ldots, 1$

Illiteracy reduction $\ldots \ldots \ldots \ldots \ldots, 1$

Industrial relations $\ldots \ldots \ldots \ldots \ldots, 1$

Labor education ..............6 6

Lay leadership $\ldots \ldots \ldots \ldots \ldots \ldots 6$

Library $\ldots \ldots \ldots \ldots \ldots \ldots \ldots \ldots .1$

Parent education .............. 2

Public adult education.......... 3

State programs of mass education. . 1

Training discussion leaders ...... 2

The kinds of institutions at which training was provided were:

Colleges and universities .........12

Extension divisions ........... 4

Community organizations $\ldots \ldots \ldots 2$

Government offices ........... 1

Membership organizations ....... 1

Agricultural extension .......... 1

Leadership training laboratory..... 1

Naval testing station $\ldots \ldots \ldots \ldots \ldots 1$

Libraries ................. 1

It is perhaps worth mentioning that only 9 of the institutions at which training was conducted are those with which members of the planning Committee are associated.

In addition to the 49 individual grants that have been mentioned, three grants were made to institutions that were willing to conduct experimental training programs. Two state universities conducted short courses to train leaders of community organizations how to conduct better meetings, and a national education association operated an experimental workshop in community analysis.

\section{Evaluating the Training}

Obviously, a lot of training was going on last winter. How effective was it? In order to find this out, the Committee asked the supervisors to fill out searching questionnaires on their respective trainees, and asked the trainees to do the same about their supervisors. It also sent Ronald Shilen to confer with all trainees and super- visors. And it brought trainees and supervisors together for a three-day exchange of experience at Ann Arbor, Michigan, early in 1953. The Committee also discovered that it needed more information than is now available about actual job opportunities and training opportunities in adult education, so it commissioned studies in both these areas.

At the end of this period of evaluation and study, the Committee reconsidered its ideas about a training program and submitted a formal proposal to the Fund for Adult Education. I shall now give the terms of this proposal, but I must make quite clear that the Fund has not yet agreed to implement this or any other training program. These proposals have been made by the Commirtee and are now being studied by the Fund.

\section{The Committee's Proposals}

The aims of the proposed program are: (1) to provide both pre-service and in-service training opportunities to both professional and lay adult educators, (2) to encourage hospitality to improvement in the practice of both formal and informal adult education, and (3) to improve the quality of both formal and informal training for adult education.

\section{Types of Trainees}

The Committee suggested that grants might well be given to the following kinds of persons:

(1) Administrators of adult education programs-for example, directors of university extension and agricultural extension, heads of library programs of adult education, YMCA general secretaries, deans of evening colleges, executive secretaries of mental hygiene clinics, heads of university departments of adult education, 
educational directors of labor unions and management organizations, and directors of public-school adult education programs.

(2) Teachers, researchers, and group workers whose primary interest is adult education-for example, teachers of adults and of adult educators, librarians doing adult education, adult activity directors in settlements and community centers.

(3) Lay leaders who carry on adult education activities on a voluntary basis-for example, leaders of civic groups and educational leaders in social service agencies, community centers, and local labor unions.

(4) Key leaders whose primary job may not be adult education but who are in strategic positions to influence the development of adult educationfor example, secretaries of group work councils, presidents of universities and teachers colleges, state library commissioners, community leaders, and leaders in business, labor, and agriculture.

Eligible persons in the above categories should, it was felt, meet one or more of the following criteria:

(1) Have authority for making policy or have personal qualities which give them far-reaching influence in the field of adult education.

(2) Have the leadership capacity and institutional relationships needed to implement in their work the experience which they would gain from a grant, and be ready to so use such experience.

(3) Be administrators or teachers concerned with training teachers of adults.

(4) Be leaders in organizations which have leadership training programs that are tied into the parent organization with some degree of permanence, so as to give continuity to the leadership development program.
(5) Be college seniors or recent graduates seeking careers in adult education.

(6) Be employed in other fields but want training to prepare them to switch to adult education.

The Committee also suggested that priority be given to persons who are employed or preparing for employment in an institution or organization in which:

(1) Education is a primary or very significant function.

(2) The educational program deals with one or more problems or issues critical to our society, in the sense that such problems relate to the individual in his capacity as a citizen who both understands the issues confronting his society and is willing and competent to take responsible action regarding such issues.

(3) The impact of the educational program extends beyond the immediate educational situation-for example, developing methods or preparing materials which have general applicability.

If persons in the adult education movement can be classified as learners, leaders, and teachers of leaders, the Committee felt that the third group, teachers of leaders, should have the first claim on grants in order to multiply the results of the program.

\section{Types of Grants}

As for the amount and type of the grants, the Committee proposed a three-year program totaling $\$ 1,850$,000 . This sum was recommended for the support of two kinds of grants: (1) study awards and (2) scholarships and fellowships.

Study awards would be made available to the whole range of potential applicants identified in preceding paragraphs, for short or long periods, 
for field projects including visits and observation, for academic study without regard to degree requirements, for supervised practice, or for attendance at workshops, institutes, or training laboratories.

Scholarships and fellowships would carry the usual meaning of these terms. That is, they would permit the recipients to engage in planned programs of training at accredited institutions of higher learning, to prepare for or to further full-time professional careers in adult education. Such grants would be made for one or more academic terms. Scholarships would normally carry lesser awards than fellowships and might be thought of as suitable for persons who wish to undertake study at a level equivalent to the Master's degree. Fellowships might be considered suitable for persons who want to undertake study at a level beyond the Master's degree.

Twice as much money was recommended for study awards as for scholarships and fellowships because the former are more flexible and will probably be more useful to most of the persons who will seek grants.

\section{Types of Training}

The Committee also made suggestions about the kinds of training situations and institutions which might be useful in the proposed program.

For example, in the case of study awards it urged that for each grantee a study plan be drawn up which would give evidence that:

(1) the proposed study program is tailored to meet the particular abilities and goals of the grantee,

(2) the grantee is given enough preparation to enable him to make good use of the training, and

(3) the training institution will provide adequate instruction and super- vision to meet the needs of the grantee.

In the case of scholarships and fellowships the Committee suggested that grantees who seek degrees or other academic training in adult education should go to institutions which have formal programs in adult education leading to advanced degrees. Grantees who seek degrees or other academic training in fields other than adult education should go to institutions which have outstanding departments in the field of specialization in question. A grantee in the latter category might well have two advisors: one in his specialty and one in adult education.

The Committee also suggested that it would be helpful if the training institution giving doctoral work in adult education:

(1) is able to adapt its program to the needs of the grantee,

(2) has strong courses in the social sciences available to grantees,

(3) has enough professional staff to give the grantee individualized instruction when needed,

(4) can provide opportunities for observation or practice in relevant areas of adult education in addition to those in which the grantee has had experience, and

(5) has a curriculum of adult education which provides opportunities for study in the following areas of adult education: history and scope, organization, psychology, curriculum problems, methods and materials, administration and supervision, and social setting.

\section{"Never Before ..."}

In submitting its proposals the Development Committee paid this tribute to the educational statesmanship of the Fund's officers: 
"To us it is a matter of no small significance that the Fund for Adult Education, faced with the necessity of a major effort in the training of adult educators, should have turned to professional representatives from the field for consultation and advice. ... Never before in the experience of the adult educators who served on this Committee has there been presented over a period of nine months the opportunity to work with the officers of an important educational foundation in a completely co-operative endeavor to hammer out in many hours of discussion the major essentials of a training program which can have a major impact on the quality and quantity of adult education leadership throughout the nation."

\section{Some Personal Comments}

The Committee's recommendations seem to me so wise in both scope and detail that I find little to add in the way of comment. I should like to say, however, that I think its members deserve special commendation because, although most of them are employed at universities, they have recognized that the bulk of the grants should be expended on flexible study awards rather than on formal study for advanced degrees. Many university professors seem to think that learning can take place only in formal courses. Even if they think otherwise, institutional pressures force them to conform. The result is that candidates for advanced degrees not only spend an undue amount of time in formal courses but are also forced to take courses that are of no use or interest to them. As a method of learning, the formal course is as wasteful of the student's time as it is economical of the professor's. The kind of training which would be most useful for me would be a combination of supervised practice, individual study, and plenty of opportunity to talk over my training experiences and study - both with my supervisors and with other trainees.

I also like the Committee's insistence on study plans which stipulate that grantees be carefully prepared for their training, that institutions be willing to adapt their training to the needs of grantees, and that institutions be able to provide enough staff to really give grantees the help they need.

The kind of training for which I expressed a preference imposes almost impossible demands on the time of supervisors. How can supervisors be induced to give so much time to trainees? By reducing their normal loads? By paying them extra? By hiring clerical or other assistants for them? By helping the trainee to realize this problem, so that he will be willing to do chores for the supervisor, chores from which he may learn nothing but which may be the only way he can compensate the supervisor for his time? I don't know. But until we face and solve this problem we shall continue to give shoddy training.

Finally, I like the implication in the Committee's recommendations that we don't know all the answers about training and that we should adopt an experimental approach toward training. This should help to keep us from freezing our training ideas and patterns and help us to develop new ones.

The Fund and the Committee have performed a great service for the adult education movement and have faced us with a great challenge. Now it is up to us to meet this challenge with imagination and resourcefulness. 